\title{
Pengujian Structure Corporate Governance terhadap Fraudulent Financial Reporting di Perusahaan Property dan Real Estate
}

\author{
Retno Tri Handayani' ${ }^{1}$ \\ ${ }^{1}$ Fakultas Ekonomi dan Bisnis, Universitas Muria Kudus \\ retno.tri@umk.ac.id
}

\begin{abstract}
Every public company must implement corporate governance structure effectively to minimize cases of fraudulent financial reporting. This opinion is based on the many cases of fraud that occur in public companies whose effects are slowly undermining the company's growth continuously until finally experiencing a dramatic bankruptcy. This study tried to examine the effect of corporate governance structure as one of the tools to minimize the practice of fraudulent financial reporting in public companies.The population used in this study was public property and real estate companies from 2013-2016 by using sampling techniques based on certain criteria. Total samples obtained were 116 companies and processed by using descriptive statistical analysis and hypothesis testing using multiple linear regression with SPSS.The results of this study indicate that the effectiveness of internal audit affects the prevention of fraudulent financial reporting, but does not succeed in showing the influence of the number of the board of commissioners on fraudulent financial reporting. This study also proved that there was no significant relationship between the board members who have international experience and the effectiveness of the audit committee with the prevention of fraudulent financial reporting.
\end{abstract}

Keywords: internal audit, audit committee, board of commissioners, financial reporting fraud

\section{ABSTRAK}

Structure corporate governance yang diterapkan secara efektif harus dilakukan oleh setiap perusahaan publik untuk meminimalisir kasus kecurangan pelaporan keuangan, pendapat ini didasari dari banyaknya kasus kecurangan yang terjadi di perusahaan publik yang imbasnya secara perlahan - lahan menggerogoti pertumbuhan perusahaan secara terus menerus hingga akhirnya mengalami kebangkrutan yang dramatis. Penelitian ini mencoba untuk menguji pengaruh structure corporate governance sebagai salah satu alat untuk meminamalisir praktik kecurangan pelaporan keuangan di perusahaan publik. Populasi yang digunakan dalam penelitian ini adalah perusahaan publik bidang property dan real estate dari tahun 2013 - 2016 dengan menggunakan teknik pengambilan sampel berdasarkan kriteria tertentu, total sampel yang diperoleh sebanyak 116 perusahaan dan diolah dengan menggunakan analisis statistik deskriptif dan pengujian hipotesis menggunakan regresi linear berganda dengan SPSS. Hasil penelitian ini menunjukkan bahwa efektifitas audit internal berpengaruh terhadap pencegahan kecurangan pelaporan keuangan, tetapi tidak berhasil menunjukkan adanya pengaruh jumlah dewan komisaris terhadap kecurangan pelaporan keuangan. Penelitian ini juga membuktikan bahwa tidak ada hubungan yang signifikan antara anggota dewan berpengalaman 
internasional dan efektifitas komite audit dengan pencegahan kecurangan pelaporan keuangan.

Kata kunci : audit internal, komite audit, dewan komisaris, kecurangan pelaporan keuangan

\section{PENDAHULUAN}

\section{Latar Belakang Penelitian}

Kecurangan pelaporan keuangan merupakan fenomena yang sudah ada sejak dulu namun masih menjadi topik yang menarik untuk dibicarakan selama masih banyak ditemukan kecurangan dalam pelaporan keuangan. Laporan keuangan sangat penting untuk kepentingan internal maupun eksternal perusahaan. Untuk kepentingan internal manajer perusahaan menggunakan laporan keuangan sebagai dasar pengambilan keputusan tentang arah kebijakan manajemen selanjutnya. Bagi pihak eksternal, laporan keuangan digunakan sebagai dasar pengambilan keputusan akan bekerja sama dengan perusahaan itu atau tidak. Kerja sama itu bisa dalam bentuk pemberian kredit, pemberian suplai barang ataupun pembelian saham perusahaan. Kecurangan pelaporan keuangan itu sendiri bisa didefinisikan sebagai penyajian laporan keuangan yang tidak disajikan sesuai dengan kondisi yang sebenarnya. Bisa dibayangkan bahwa kecurangan laporan keuangan akan mengaburkan pada kondisi pengambilan keputusan yang sebenarnya.

Iqbal dan Murtanto (2016) pun mengemukakan bahwa para pelaku bisnis harus dapat memberikan informasi yang akurat dan relevan serta terbebas dari adanya kecurangan yang akan sangat menyesatkan para pengguna laporan keuangan dalam proses pengambilan keputusan. Salah saji dalam laporan keuangan pun bisa dikategorikan sebagai kecurangan pelaporan keuangan mengingat kaburnya kondisi laporan keuangan yang sebenarnya. Manajer sebagai pihak yang bertanggung jawab memanajemen perusahaan tentu menginginkan laporan keuangan dalam kondisi baik. Hal inilah terkadang yang menjadikan motivasi manajer perusahaan-perusahaan tertentu untuk melakukan kecurangan pelaporan keuangan. Kecurangan pelaporan keuangan jelas merugikan pihak lain karena berhubungan dengan pengambilan keputusan langkah-langkah ekonomi selanjutnya. Langkah-langkah ekonomi yang diambil berdasarkan laporan keuangan yang tidak semestinya tentu akan mengarah pada keputusan yang salah.

Penelitian tentang hubungan antara structure corporate governance dengan kecurangan pelaporan keuangan memang sudah banyak dilakukan. Akan tetapi mengingat masih belum konsisten dalam hasilnya sehingga dirasa masih sangat perlu meneliti tentang hal ini. Hasil penelitian Alzoubi dan Selamet (2012) menyatakan bahwa jumlah anggota dewan yang sedikit akan lebih efektif sehingga mengurangi potensial kecurangan laporan keuangan. Sukeecheep, Yarram dan Al Faraque (2013) menyatakan bahwa tidak ada hubungan yang signifikan antara ukuran dewan dan pengawasan dengan kualitas pelaporan keuangan. Hardiningsih (2010) membuktikan bahwa komite audit, komisaris independen, ukuran dewan komisaris, dan kepemilikan institusional tidak berpengaruh terhadap integritas laporan keuangan. Integritas laporan keuangan ini tentu ada hubungannya dengan ada tidaknya kecurangan laporan keuangan. Jannah (2016) membuktikan bahwa penerapan prinsip-prinsip good corporate governance berpengaruh positif terhadap pencegahan fraud Bank Perkreditan Rakyat di Surabaya. Penelitian tentang pengaruh struktur corporate governance terhadap kecurangan pelaporan keuangan juga sudah dilakukan oleh Widodo dan Syafruddin 
(2017). Beda penelitian ini dengan penelitian sebelumnya adalah pada perbedaan tahun sampel (2013 sd 2016) dan tidak adanya keberadaan KAP Big-4.

\section{Perumusan Masalah}

1. Apakah berpengaruh atau tidak jumlah anggota dewan komisaris terhadap fraudulent financial reporting?

2. Apakah berpengaruh atau tidak adanya anggota dewan dengan pengalaman internasional terhadap fraudulent financial reporting?

3. Apakah berpengaruh atau tidak efektivitas komite audit terhadap fraudulent financial reporting?

4. Apakah berpengaruh atau tidak efektivitas audit internal terhadap fraudulent financial reporting?

\section{Tujuan Penelitian}

1. Untuk mengetahui berpengaruh atau tidak jumlah anggota dewan komisaris terhadap fraudulent financial reporting.

2. Untuk mengetahui berpengaruh atau tidak adanya anggota dewan dengan pengalaman internasional terhadap fraudulent financial reporting.

3. Untuk mengetahui berpengaruh atau tidak efektivitas komite audit terhadap fraudulent financial reporting.

4. Untuk mengetahui berpengaruh atau tidak efektivitas audit internal terhadap fraudulent financial reporting.

\section{Manfaat Penelitian}

Penelitian ini diharapkan dapat memberikan bukti apakah structure corporate governance dapat mencegah kecurangan pelaporan keuangan atau tidak. Dengan demikian akan diketahui secara lebih pasti apa saja yang dapat mencegah ataupun mengurangi kecurangan pelaporan keuangan. Dan dengan berkurangnya kecurangan pelaporan keuangan diharapkan kepercayaan investor meningkat yang bisa berdampak pada tumbuhnya perekonomian di Indonesia.

\section{TELAAH LITERATUR DAN PENGEMBANGAN HIPOTESIS}

\section{Fraud}

Kecurangan laporan keuangan (fraud) merupakan perilaku atau tindakan kesengajaan yang dilakukan oleh seseorang untuk memanipulasi dan mencurangi laporan keuangan untuk kepentingan pribadi, ataupun golongan tertentu (Fitri dan Chintia, 2015). Laporan keuangan digunakan untuk pengambilan keputusan baik itu untuk kepentingan internal maupun eksternal perusahaan. Kecurangan laporan keuangan tentu akan menyesatkan keputusan bagi stakeholder perusahaan.

\section{Teori Keagenan (Agency Theory)}

Iqbal dan Murtanto (2016) menyatakan bahwa teori keagenan mendeskripsikan hubungan antara 
pemegang saham (shareholder) sebagai principal dan manajemen sebagai agen. Pihak manajemen sebagai pihak yang mengelola perusahaan pasti mengenal lebih dalam tentang kondisi keuangan perusahaan. Untuk menunjukkan kinerjanya yang baik sebagai pihak yang bertanggungjawab atas jalannya perusahaan maka tidak mengherankan banyak pihak manajemen yang termotivasi untuk memanipulasi laporan keuangan yang sebenarnya.

\section{Structure Corporate Governance}

Corporate Governance merupakan salah satu elemen kunci dalam meningkatkan efisiensi ekonomis, yang meliputi serangkaian hubungan antara manajemen perusahaan, dewan komisaris, para pemegang saham dan stakeholder lainnya yang juga memberikan suatu struktur yang memfasilitasi penentuan sasaran-sasaran dari suatu perusahaan, dan sebagai sarana untuk menentukan teknik monitoring kerja (Darmawati, Khomsiyah \& Rahayu, 2004). Tata kelola perusahaan atau corporate governance yang diterapkan secara efektif diharapkan mampu mencegah terjadinya kecurangan pelaporan keuangan yang dilakukan oleh pihak manajer.

Sedangkan menurut Manik (2013) kecurangan korporasi dari para pemimpin perusahaan memiliki kekuatan dan kesempatan khususnya dalam penerapan corporate governance karena mereka diberi wewenang untuk mengatur, mengelola dan mengawasi proses aktivitas perusahaan dalam meningkatkan laba dan asset selama periode akuntansi. Kecurangan pelaporan keuangan yang dilakukan secara korporasi justru akan ditunjang dengan adanya penerapan corporate governance.Adapun dalam penelitian ini structure corporate governance dinyatakan dalam jumlah anggota dewan komisaris, anggota dewan dengan pengalaman internasional, efektivitas komite audit dan efektivitas audit internal.

\section{Jumlah Anggota Dewan Komisaris}

Alzoubi dan Selamet (2012) mengemukakan bahwa anggota dewan komisaris bertanggung jawab dalam menentukan tujuan dan strategi organisasi serta menyelaraskannya dengan kepentingan pemegang saham. Jadi dalam hal ini dewan komisaris bertanggung jawab terhadap para pemegang saham. Untuk hasil penelitian tentang jumlah anggota dewan komisaris dengan kecurangan pelaporan keuangan masih beragam hasilnya sehingga menarik untuk dilakukan penelitian lebih lanjut. Jumlah anggota dewan yang sedikit adalah lebih efektif karena mudah untuk mengelolanya dan mereka dapat memiliki komunikasi yang efektif dan mengurangi potensi kesalahpahaman (Alzoubi dan Selamet, 2012). Dari penelitian Alzoubi dan Selamet ini dapat disimpulkan bahwa jumlah anggota dewan yang sedikit lebih mampu mencegah terjadinya kecurangan pelaporan keuangan. Ukuran dewan yang terlalu kecil dan terlalu besar sebenarnya tidak terlalu efektif (Karamanou \& Vafeas, 2005).

Sedangkan Sukeecheep, Yarram dan Al Faraqoue (2013) dan Abbot, Park, \& Parker (2000) menemukan bahwa tidak ada hubungan yang signifikan antara ukuran dewan dan pengawasan dalam kualitas pelaporan keuangan. Jumlah anggota dewan komisaris yang semakin kecil, diharapkan lebih efektif dalam pengawasan terhadap pimpinan manajemen puncak sehingga berdampak menurunnya kemungkinan terjadinya kecurangan pelaporan keuangan. Dalam penelitian ini dapat dirumuskan hipotesis: 
H1 : Jumlah anggota dewan komisaris berpengaruh positif dengan kecurangan pelaporan keuangan.

\section{Anggota Dewan Dengan Pengalaman Internasional}

Carpenter dan Feroz (2001) berpendapat bahwa anggota dewan dengan pengalaman internasional merupakan individu yang memiliki nilai lebih, langka, dan memiliki sifat karakteristik yang tidak ada bandingannya yang dapat berkontribusi pada keunggulan kompetitif dari perusahaan yang menggunakan pengalaman mereka. Dengan adanya anggota dewan perusahaan yang memiliki pengalaman internasional diharapkan lebih memiliki wawasan dan pengalaman yang lebih banyak sehingga mampu mengurangi jumlah kecurangan pelaporan keuangan. Dalam penelitian ini dapat dirumuskan hipotesis:

$\mathrm{H} 2$ : Jumlah anggota dewan dengan pengalaman internasional berpengaruh negatif dengan kecurangan pelaporan keuangan.

\section{Efektivitas Komite Audit}

Coram, Ferguson dan Moroney (2006) memberikan bukti bahwa manajemen laba dapat dicegah dengan memiliki komite audit yang efektif dalam organisasi. Prasetyo (2014) membuktikan bahwa komite audit independen dan jumlah rapat komite audit tidak berpengaruh signifikan terhadap kecurangan pelaporan keuangan.Corporate Governance yang baik diharapkan mampu mencegah terjadinya kecurangan pelaporan keuangan. Salah satu corporate governance diantaranya adanya komite audit, maka dalam penelitian ini memutuskan untuk merumuskan hipotesis sebagai berikut:

H3 : Efektivitas komite audit berpengaruh positif dalam mencegah kecurangan pelaporan keuangan.

\section{Efektivitas Audit Internal}

Audit internal merupakan audit dari dalam perusahaan itu sendiri yang bertujuan untuk memastikan bahwa segala sesuatunya telah berjalan sesuai standar ataupun peraturan dalam perusahaan tersebut. Audit internal yang efektif diharapkan mampu mencegah kecurangan pelaporan keuangan. Hasil penelitian Widodo dan Syafruddin (2017) menunjukkan bahwa efektivitas internal audit berpengaruh positif dalam mengurangi kecurangan pelaporan keuangan.

H4 : Efektivitas audit internal berpengaruh positif dalam mencegah kecurangan pelaporan keuangan.

\section{METODE PENELITIAN}

\section{Populasi dan Sampel}

Populasi dalam penelitian ini adalah perusahaan property dan real estate yang terdaftar di BEl periode 2013-2016. Pengambilan sampel dalam penelitian ini menggunakan metode purposive sampling. Sampel yang digunakan dalam penelitian ini menggunakan kriteria sebagai berikut : perusahaan property dan real estate yang Go Public selama periode 2013-2016, perusahaan property dan real estateperiode 2013-2016 dalam website www.idx.co.id yang mempublikasikan laporan keuangan tahunannya sudah teraudit oleh auditor independen, perusahaan yang tidak pernah mengalami kerugian selama periode 2013-2016. 


\section{Jenis dan Sumber Data}

Jenis data yang digunakan dalam penelitian ini adalah data sekunder yang merupakan data yang diperoleh dari pihak lain. Data dalam penelitian ini merupakan data perusahaan property dan real estate periode 2013-2016 yang diperoleh dari website www.idx.co.id.

\section{Metode Pengumpulan Data}

Pengumpulan data dilakukan dengan metode dokumentasi, dengan cara mengumpulkan, mencatat, mengkaji data sekunder yang berupa laporan keuangan tahunan perusahaan property dan real estate periode 2013-2016.

\section{Metode Analisis Data}

Analisis statistik yang digunakan dalam penelitian ini adalah sebagai berikut.

1. Statistik Deskriptif

Untuk menghitung rata-rata, standar deviasi, minimum dan maksimum variabel-variabel dalam penelitian. Statistik deskriptif bertujuan memberikan gambaran data suatu penelitian.

2. Uji Asumsi Klasik

Digunakan untuk mengetahui apakah model regresi yang digunakan dalam penelitian ini baik atau tidak. Uji asumsi klasik yang digunakan dalam penelitian ini diantaranya adalah uji multikolonieritas, uji autokorelasi, uji heteroskedastisitas dan uji normalitas.

3. Analisis Regresi Linier Berganda

Untuk menguji hipotesis, penelitian ini menggunakan analisis regresi linier berganda. Menurut Sanusi (2011:135) regresi linier berganda dinyatakan dalam persamaan matematika sebagai berikut:

$$
\mathrm{Y}=\mathrm{C}+b_{1} X_{1}+b_{2} X_{2}+b_{3} X_{3}+b_{4} X_{4}+\mathrm{T} \varepsilon
$$

Keterangan disesuaikan dengan variabel dalam penelitian ini:

Y : Fraudulent Financial Reporting

C : Konstanta

$\mathrm{b} X_{1} \quad$ : Koefisien regresi Jumlah Anggota Dewan Komisaris

$\mathrm{b} \mathrm{X}_{2} \quad$ : Koefisien regresi Anggota Dewan dengan Pengalaman Internasional

$\mathrm{b} X_{3} \quad$ :Koefisien regresi Efektivitas Komite Audit

$\mathrm{b} X_{4} \quad$ :Koefisien regresi Efektivitas Audit Internal

Te :Total Error

\section{HASIL DAN PEMBAHASAN}

\section{Analisis Deskriptif}

Penelitian ini menggunakan analisis statistik deskriptif untuk memperlihatkan persebaran data penelitian. Statistik deskriptif dalam penelitian ini menyajikan nilai rata-rata (mean), standar deviasi, nilai maksimum 
dan nilai minimum variabel dalam penelitian ini. Populasi penelitian ini adalah perusahaan property dan real estate yang terdaftar di BEI periode 2013 sd 2016 (4tahun). Penentuan sampel penelitian ini menggunakan tehnik purposive sampling. Teknik pengambilan sampel dengan metode purposive sampling yaitu penentuan sampel berdasarkan pertimbangan tertentu (Sugiyono, 2014). Penelitian ini menggunakan sampel perusahaan property dan real estate yang terdaftar di BEl dalam kurun waktu 4 tahun (2013 sd 2016). Kriteria yang digunakan untuk penentuan sampel dalam penelitian ini yaitu:

1. Perusahaan property dan real estate yang go public selama periode 2013 sd 2016 atau website www. idx.co.id

2. Perusahaan property dan real estate yang telah mempublikasikan laporan keuangan dan laporan tahunannya selama periode 2013 sd 2016 serta telah diaudit oleh auditor independen.

3. Tidak pernah mengalami kerugian selama periode 2013 sd 2016.

4. Memiliki data lengkap terkait dengan variabel dalam penelitian ini.

Tabel 1. Descriptive Statistics

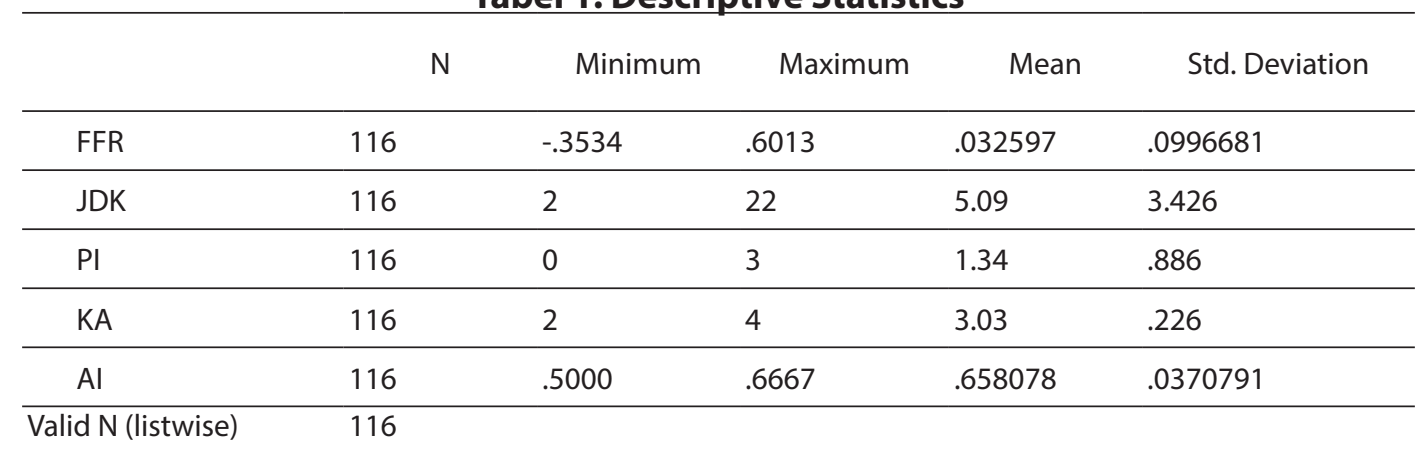

Jumlah sampel perusahaan yang memenuhi kriteria di atas berjumlah 29 dengan 4 tahun sehingga total sampel dalam penelitian ini berjumlah 116. Dari table statistic di atas terlihat bahwa rata-rata tertinggi oleh variabel jumlah dewan komisaris (JDK) sedangkan rata-rata terendah oleh variabel fraud financial reporting (FFR).

\section{Uji Asumsi Klasik}

Uji asumsi klasik yang digunakan dalam penelitian ini diantaranya adalah uji multikolonieritas, 'uji autokorelasi, uji heteroskedastisitas, dan uji normalitas. Adapun hasil dan penjelasannya adalah sebagai berikut.

\section{Uji Multikolonieritas}

Hasil uji multikolonieritas tabel di atas menunjukkan bahwa tidak ada variabel independen yang memiliki nilai Tolerance kurang dari 0.10. Hasil perhitungan nilai VIF juga menunjukkan tidak ada variabel independen yang memiliki nilai VIF lebih dari 10. Jadi dapat disimpulkan dalam uji regresi penelitian ini tidak terdapat multikolonieritas antar variabel independen. 
Tabel 2. Uji Multikolinearitas

\begin{tabular}{|c|c|c|c|c|c|c|c|c|}
\hline \multicolumn{9}{|c|}{ Coefficients ${ }^{2}$} \\
\hline \multirow[b]{2}{*}{ Mod } & & \multicolumn{2}{|c|}{ Unstandardized Coefficients } & \multirow{2}{*}{$\begin{array}{c}\begin{array}{c}\text { Standardized } \\
\text { Coefficients }\end{array} \\
\text { Beta }\end{array}$} & \multirow[b]{2}{*}{$t$} & \multirow[b]{2}{*}{ Sig. } & \multicolumn{2}{|c|}{ Collinearity Statistics } \\
\hline & & B & Std. Error & & & & Tolerance & $\mathrm{V} \mid \mathrm{F}$ \\
\hline \multirow[t]{5}{*}{1} & (Constant) & -.404 & .347 & & -1.165 & .247 & & \\
\hline & JDK & .009 & .005 & .317 & 1.768 & .080 & .246 & 4.061 \\
\hline & $\mathrm{PI}$ & -.005 & .013 & -.047 & -.396 & .693 & .556 & 1.800 \\
\hline & $\mathrm{KA}$ & -.089 & .058 & -.202 & -1.530 & .129 & .455 & 2.200 \\
\hline & Al & 1.014 & .381 & .377 & 2.659 & .009 & .393 & 2.544 \\
\hline
\end{tabular}

a. Dependent Variable: FFR

\section{Uji Autokorelasi}

\section{Tabel 3. Uji Autokorelasi}

\section{Model Summary ${ }^{b}$}

\begin{tabular}{|l|l|l|r|r|r|}
\hline $\begin{array}{l}\text { Mode } \\
1\end{array}$ & $\mathrm{R}$ & R Square & $\begin{array}{c}\text { Adjusted R } \\
\text { Square }\end{array}$ & $\begin{array}{c}\text { Std. Error of } \\
\text { the Estimate }\end{array}$ & $\begin{array}{c}\text { Durbin- } \\
\text { Watson }\end{array}$ \\
\hline 1 & $.349=$ & .122 & .090 & .0950791 & 2.014 \\
\hline
\end{tabular}

a. Predictors: (Constant), $\mathrm{Al}, \mathrm{PI}, \mathrm{KA}, \mathrm{JDK}$

b. Dependent Variable: FFR

Hasil uji autokorelasi terlihat bahwa nilai DW (Durbin-Watson) sebesar 2.014. Nilai tabel dengan nilai signifikansi 5\%, k=4 dan nilai sampel 116 menunjukkan angka 1.758. Dapat disimpulkan bahwa tidak terdapat autokorelasi mengingat nilai DW 2.014 lebih besar dari 1.758.

\section{Uji Heteroskedastisitas}

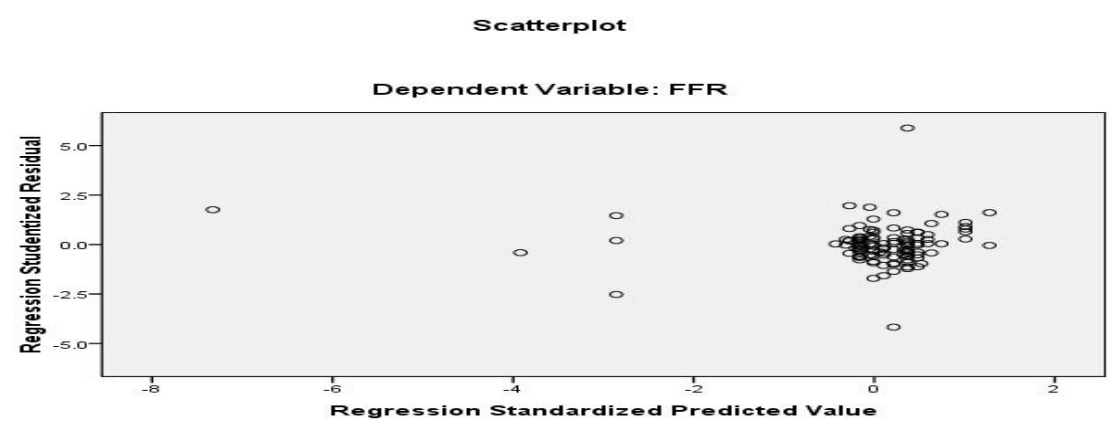

\section{Gambar 1. Uji Heteroskedastisitas}

Dari grafik di atas terlihat bahwa titik-titik menyebar secara acak maka dapat disimpulkan tidak terdapat heterokedastisitas dalam model regresi penelitian ini. 


\section{Uji Normalitas}



\section{Gambar 1. Uji Normalitas dengan Grafik}

Normal P-P Plot of Regression Standardized Residual

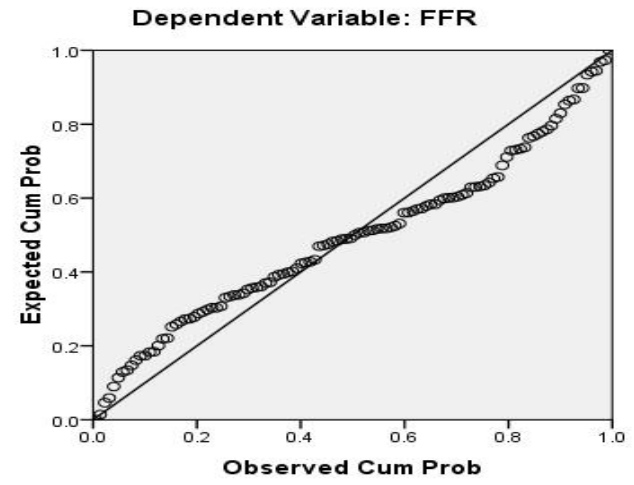

\section{Gambar 2. Uji Normalitas dengan Scatter Plot}

Dari tabel histogram terlihat bahwa pola distribusi normal sedangkan pada grafik normal plot juga terlihat bahwa titik-titik menyebar di sekitar garis diagonal. Hal ini menunjukkan bahwa model regresi memenuhi asumsi normalitas.

\section{Uji Regresi}

Berdasarkan hasil uji regresi linier berganda mengenai pengaruh jumlah anggota dewan komisaris terhadap kecurangan pelaporan keuangan menunjukkan nilai 0.080. Hasil itu menunjukkan bahwa jumlah anggota dewan komisaris tidak mempunyai pengaruh yang signifikan terhadap kecurangan pelaporan keuangan sehingga hipotesis pertama ditolak. Hasil penelitian ini mampu mendukung pernyataan Wicaksono dan Chariri (2015) bahwa dengan jumlah anggota dewan komisaris yang semakin banyak, tidak secara efektif 


\section{Tabel 5. Uji Regresi}

\begin{tabular}{|c|c|c|c|c|c|c|}
\hline \multicolumn{7}{|c|}{ Coefficients ${ }^{a}$} \\
\hline \multirow{2}{*}{\multicolumn{2}{|c|}{ Madel }} & \multicolumn{2}{|c|}{ Unstandardized Coefficients } & \multirow{2}{*}{$\begin{array}{c}\begin{array}{c}\text { Standardized } \\
\text { Coefficients }\end{array} \\
\text { Beta } \\
\end{array}$} & \multirow[b]{2}{*}{$t$} & \multirow[b]{2}{*}{ Siq. } \\
\hline & & $\mathrm{B}$ & Std. Error & & & \\
\hline \multirow[t]{5}{*}{1} & (Constant) & -.404 & .347 & & -1.165 & 247 \\
\hline & JDK & .009 & .005 & .317 & 1.768 & .080 \\
\hline & $\mathrm{PI}$ & -.005 & .013 & -.047 & -.396 & .693 \\
\hline & $K A$ & -.089 & .058 & -.202 & -1.530 & .129 \\
\hline & Al & 1.014 & .381 & .377 & 2.659 & .009 \\
\hline
\end{tabular}

a. Dependent Variable: FFR

dapat melakukan pengawasan terhadap dewan direksi dan tidak dapat meningkatkan kinerja manajemen suatu perusahaan dalam pencegahan fraud. Structure corporate governance khususnya dalam hal jumlah anggota dewan komisaris tidak mampu mengurangi secara signifikan kasus kecurangan dalam pelaporan keuangan. Hal ini konsisten dengan penelitian yang dilakukan oleh Razali dan Arshad (2014).

Berdasarkan hasil uji regresi linier berganda mengenai pengaruh anggota dewan dengan pengalaman internasional terhadap kecurangan pelaporan keuangan menunjukkan nilai 0.693. Hasil itu menunjukkan bahwa anggota dewan dengan pengalaman internasional tidak mempunyai pengaruh yang signifikan terhadap kecurangan pelaporan keuangan sehingga hipotesis kedua ditolak. Anggota dewan dengan pengalaman internasional tidak bisa mencegah kecurangan pelaporan keuangan secara signifikan mengingat situasi dan kondisi yang berbeda antara praktek di Indonesia dengan yang terjadi di lain negara.

Berdasarkan hasil uji regresi linier berganda mengenai pengaruh efektifitas komite audit terhadap pencegahan kecurangan pelaporan keuangan menunjukkan nilai 0.129. Hasil itu menunjukkan bahwa efektifitas komite audit tidak mempunyai pengaruh yang signifikan terhadap pencegahan kecurangan laporan keuangan sehingga hipotesis ketiga ditolak. Seefektif apapun komite audit, dalam pekerjaannya tetap harus berkoordinasi dengan dewan direksi yang berhubungan dengan kegiatan operasional perusahaan sehari-hari. Hal itu memungkinkan masih ada celah untuk terjadinya kecurangan pelaporan keuangan, walaupun hanya sedikit sekali kemungkinannya.

Berdasarkan hasil uji regresi linier berganda mengenai pengaruh efektifitas audit internal terhadap pencegahan kecurangan pelaporan keuangan menunjukkan nilai 0.009. Hasil itu menunjukkan bahwa efektifitas audit internal berpengaruh terhadap pencegahan kecurangan pelaporan keuangan sehingga hipotesis keempat diterima. Hasil uji regresi linier berganda yang menunjukkan hasil positif memberikan bukti bahwa semakin efektif sebuah audit internal dalam sebuah perusahaan maka akan semakin besar pula kemungkinan berhasilnya pencegahan kecurangan pelaporan keuangan dalam perusahaan tersebut. Audit internal yang efektif akan melakukan pengawasan secara berkala terhadap operasional sebuah perusahaan sehingga akan mempersempit kesempatan terjadinya kecurangan pelaporan keuangan. 


\section{KESIMPULAN}

Berdasarkan hasil uji regresi berganda dalam penelitian ini dapat disimpulkan bahwa hanya variabel efektifitas audit internal yang berpengaruh terhadap pencegahan kecurangan pelaporan keuangan. Penelitian ini tidak berhasil menunjukkan adanya pengaruh jumlah dewan komisaris terhadap kecurangan pelaporan keuangan. Penelitian ini juga membuktikan bahwa tidak ada hubungan yang signifikan antara anggota dewan berpengalaman internasional dan efektifitas komite audit dengan pencegahan kecurangan pelaporan keuangan.

Keterbatasan penelitian ini hanya meneliti pada perusahaan property dan real estate. Untuk penelitian selanjutnya bisa meneliti pada sampel yang berbeda sehingga bisa semakin memperkuat kesimpulan bagaimana pengaruh structure corporate governance dengan kecurangan pelaporan keuangan.

\section{DAFTAR PUSTAKA}

Abbott, L.J., Park, Y., and Parker, S. (2000). The effects of Audit Committee Activity and Independence On Corporate Fraud. Management Finance, Vol.26, No.11, halm. 55-67.

Alzoubi, E.S.S., Selamet, M.H. (2012). “The Effectiveness Of Corporate Governance Mechanisms On Constraining Earning Management: Literature Review and Proposal Framework". International Journal of Global Bussiness Vol.5 No.1 h.48-52.

Carpenter, V.L and Feroz, E.H. 2001. Institusional Theory and Accounting Rule Choice An Analysis of Four US State Government's Decisions To Adopt Generally Accepted Accounting Principles. Accounting Organizations and Society, Vol.26., halm. 565-596.

Coram, P., Ferguson, C., and Moroney, R. 2006. The Importance of Internal Audit In Fraud Detection. Research Journal.

Darmawati, D., Khomsiyah, K., dan Rahayu, R.G. (2004). Hubungan Corporate Governance dan Kinerja Perusahaan. Simposium Nasional Akuntansi VII, IAI, 2004.

Hardiningsih, P. (2010). "Pengaruh Independensi, Corporate Governance dan Kualitas Audit Terhadap Integritas Laporan Keuangan." Kajian Akuntansi Februari 2010 hal: 61-76.

Ismiyanti F., \& Prastichia C. (2015). Mekanisme Corporate Governance dan Kecurangan Laporan Keuangan".

DeReMa Jurnal Manajemen Vol.10 No 2 September 2015.

Iqbal M., dan Murtanto. (2016). “Kecurangan Laporan Keuangan: Analisa Faktor-Faktor Fraud Triangle Pada Perusahaan Property Dan Real Estate". Seminar Nasional Cendekiawan.

Jannah, F.S. (2016). Pengaruh Good Corporate Governance Terhadap Pencegahan Fraud Di Bank Perkreditan Rakyat. AKRUAL 7 (2) (2016): 177-191.

Manik, Tumpal. (2013). Pengendalian Corporate Fraud Melalui Penerapan Corporate Governance, Manipulasi Harga Pokok Penjualan dan Beban Operasional Terhadap Kinerja Perusahaan. JEMI Vol. 4 No 1, Hal 1.

Karamanou, I., \& Vafeas, N. (2005). The Association between Corporate Boards, Audit Committees, and Management Earnings Forecasts: An Empirical Analysis. Journal of Accounting Research Vol. 43 No. 3 
June 2005 Printed in U.S.A.

Prasetyo, A.B. (2014). Pengaruh Karakteristik Komite Audit dan Perusahaan Terhadap Kecurangan Pelaporan Keuangan (Studi Empiris pada Perusahaan yang Listed di Bursa Efek Indonesia Periode 2006-2010). Jurnal Akuntansi \& Auditing Volume 11 No. 1/ November 2014 : 1 - 24

Razali, Wan Ainul A.W.M dan Arshad R. 2014. Disclosure of Corporate Governance Structure and The Likelihood of Fraudulent Financial Reporting. Accounting Research Institude, Vol 145: 243-253.

Sanusi, Anwar. 2011. Metodologi Penelitian Bisnis. Jakarta : Salemba Empat.

Sugiyono. 2014. Metode Penelitian Kuantitatif, Kualitatif, dan R \& D. Bandung: Alfabeta.

Sukeecheep, S., Yarram, S.R., and AI Farooque, O. (2013). Earnings Management and board characteristics in Thai Listed Companies. The 2013 IBEA. International Conference on Business, Economics, and Accounting.

Wicaksono G. S., dan Chariri A. 2015. Mekanisme Corporate Governance dan Kemungkinan Kecurangan Dalam Pelaporan Keuangan. Diponegoro Journal of Accounting. Volume 4, Nomor 4, Tahun 2015, Halaman 1.

Widodo, A.,\& Syafruddin, M. (2017). "Pengaruh Pengungkapan Struktur Corporate Governance Terhadap Kecurangan Pelaporan Keuangan". Diponegoro Journal Of Accounting. 